\title{
Sources and Effectiveness of Potato PVY Resistance in IHAR's Breeding Research
}

\author{
Ewa Zimnoch-Guzowska • Zhimin Yin • \\ Mirosława Chrzanowska $\cdot$ Bogdan Flis \\ Published online: 5 January 2013 \\ (C) The Author(s) 2012. This article is published with open access at Springerlink.com
}

\begin{abstract}
Resistance to Potato virus $Y$ (PVY) is one of the most important traits in seed and ware potato production. Currently the tobacco-necrosis inducing $\mathrm{PVY}^{\mathrm{N}}$ strain including $\mathrm{PVY}^{\mathrm{N}-\mathrm{Wi}}$ and $\mathrm{PVY}^{\mathrm{NTN}}$ dominates in the PVY population in Poland. The PVY ${ }^{\mathrm{O}}$ strain which dominated in early $1980 \mathrm{~s}$ is rarely detected. Since early 1950s, breeding for PVY resistance in IHAR was a part of the program developing parental lines, which resulted in selecting lines extremely resistant to PVY. The selection of these lines was improved by the application of developed molecular markers. Moreover, the group of genes conferring comprehensive hypersensitive resistance (HR) to all strains of PVY was identified and mapped. The cultivars obtained from parental lines have enhanced level of resistance to PVY. For registered cultivars, the level of resistance to PVY is monitored in field exposure tests, while the reaction to four different isolates of PVY is examined by artificial inoculations. The 36 cultivars with field resistance scores 7.5 and 9 expressed resistance to all tested isolates and 23 of them originated from IHAR parental lines. Several moderately resistant cultivars varied in sensitivity to the PVY isolates and in majority they were more sensitive to isolates Wi (collected in 1984) and 12/94 (collected in 1994), than to older isolates LW and Ny collected in 1970-ties.
\end{abstract}

This paper is an invited presentation as part of the International Symposium on PVY sponsored by the Plant Protection Section of the Potato Association of America, August 11, 2009, in Fredericton, New Brunswick, Canada. This paper was reviewed with a view to ensure that the information was brought up-to-date beyond what was given at the time of the presentation.

E. Zimnoch-Guzowska $(\bowtie) \cdot$ Z. Yin $\cdot$ M. Chrzanowska $\cdot$ B. Flis Młochów Research Center, Plant Breeding and Acclimatization Institute - National Research Institute (IHAR-PIB),

Platanowa Str. 19,

05-831 Młochów, Poland

e-mail: e.zimnoch-guzowska@ihar.edu.pl
Resumen La resistencia al virus Y de la papa (PVY) es uno de los caracteres más importantes en la producción de papa para semilla y consumo. Actualmente, la variante que induce necrosis en tabaco $\mathrm{PVY}^{\mathrm{N}}$ incluyendo $\mathrm{PVY}^{\mathrm{N}-\mathrm{Wi}}$ y $\mathrm{PVY}^{\mathrm{NTN}}$ domina en la población de PVY en Polonia. Se detecta raramente la variante $\mathrm{PVY} \mathrm{O}^{\mathrm{O}}$ que dominó a principio de los 1980s. Desde el inicio de los 1950s el mejoramiento para resistencia a PVY en IHAR era parte del programa para el desarrollo de líneas parentales, lo que resultó en la selección de líneas extremadamente resistentes al PVY. Se mejoró la selección de estas líneas mediante la aplicación de marcadores moleculares desarrollados. Más aún, se identificó y mapeó el grupo de genes que confieren reacciones de hipersensibilidad (HR) que incluyen a todas las variantes de PVY. Las variedades que se obtuvieron de las líneas parentales han incrementado su nivel de resistencia al PVY. Para variedades registradas, se monitorea el nivel de resistencia al PVY en pruebas de exposición en el campo, mientras que se examina la reacción a cuatro variantes diferentes de PVY mediante inoculaciones artificiales. Las 36 variedades con resistencia de campo alcanzan calificaciones de 7.5. Nueve expresaron resistencia a todos los aislamientos probados, y 23 de ellas se originaron de líneas parentales de IHAR. Diversas variedades moderadamente resistentes fluctuaron en sensibilidad a los aislamientos de PVY y en su mayoría fueron más sensibles a los aislamientos Wi (colectados en 1984) y 12/94 (colectados en 1994), que a aislamientos más viejos LW y Ny colectados en los 1970s.

Keywords Monitoring $\cdot$ PVY population $\cdot$ Parental line breeding $\cdot$ Cultivar reaction

\section{Introduction}

Potato is one of the strategic crops in Polish agriculture. In 2009 potato crop, despite decreasing tendency observed in the last decade, approximately 600 thousand ha were planted with 
12 million tonnes of total yield. The seed production in the country was held on 5000 ha with the total seed tuber yield of 60 thousand tonnes. The low rate of certified seeds planted by farmers (about $8 \%$ ) leads to a high Potato virus $Y$ (PVY) infection of widely grown cultivars for fresh market and processing. Losses in potato crop due to infection with PVY might vary between 10 and $90 \%$ and result from decreased size and number of harvested tubers (Jeffries 1998; Novy et al. 2002). Occurrence of the PVY ${ }^{\mathrm{NTN}}$ variant, which induces potato tuber necrotic ringspot disease (PTNRD), causes additional quality losses in table and processed cultivars. Breeding against sensitivity to PTNRD has increasing importance in the selection of new cultivars (Valkonen 2007).

Resistance to PVY is one of the most important resistance traits in seed and ware potato production in Poland. This paper presents the elements of breeding research focused on changes in the structure of PVY population, breeding for resistance to PVY and evaluation of reaction to various PVY strains in cultivars registered in Poland.

\section{Structure of PVY Population in Poland}

The PVY population at Młochów (central Poland) has been monitored continuously on tobacco (cv. Samsun) bait plants mostly every second year since 1980 . Based on ELISA results with strain specific mAbs and non-specific $\mathrm{Ab}$ and on symptoms on tobacco, the isolates were classified into $\mathrm{PVY}^{\mathrm{O}}$ $\left(\mathrm{PVY}^{\mathrm{O}}\right.$ serotype, vein clearing on tobacco), $\mathrm{PVY}^{\mathrm{N}}\left(\mathrm{PVY}^{\mathrm{N}}\right.$ serotype, vein necrosis on tobacco) and $\mathrm{PVY}^{\mathrm{N}-\mathrm{Wi}}\left(\mathrm{PVY}^{\mathrm{O}}\right.$ serotype, vein necrosis on tobacco) strain groups. Selected isolates showing positive reaction to $\mathrm{PVY}^{\mathrm{N}} \mathrm{mAb}$ were tested on sensitive potato $\mathrm{cv}$. Vital, Igor and Nicola. The isolates invoking necroses on tubers were classified as $\mathrm{PVY}^{\mathrm{NTN}}$ strain. All tested $\mathrm{PVY}^{\mathrm{N}}$ isolates induced PTNRD, indicating a $\mathrm{PVY}^{\mathrm{NTN}}$ strain type. As shown in Fig. 1, in early 1980s PVY strain was up to $85-90 \%$ of the PVY population and it had dropped below $10 \%$ since 1986. From 1984 to $2004 \mathrm{PVY}^{\mathrm{N}-\mathrm{Wi}}$ strain had dominated in the PVY population (Chrzanowska 1991 ) and then decreased to $32 \%$ in 2008 . However, in 2010 , $\mathrm{PVY}^{\mathrm{N}-\mathrm{Wi}}$ became the dominant form again $(62 \%) . \mathrm{PVY}^{\mathrm{N}}$ and/or PVY ${ }^{\mathrm{NTN}}$ strain had gradually increased since 1994 (Chrzanowska and Doroszewska 1997). In 2004, a significant increase of $\mathrm{PVY}^{\mathrm{N}}$ and/or $\mathrm{PVY}^{\mathrm{NTN}}$ frequency was noted and it reached $66 \%$ of the population in 2008. Among the isolates tested in 2010, $14 \%$ reacted positively to both $\mathrm{PVY}^{\mathrm{N}}$ and $\mathrm{PVY}^{\mathrm{O}}$ specific $\mathrm{mAb}$, what might be indication of mixed infection.

Our study showed that currently the tobacco-necrosis inducing $\mathrm{PVY}^{\mathrm{N}}$ strain including variant isolates $\mathrm{PVY}^{\mathrm{N}-\mathrm{Wi}}$ and $\mathrm{PVY}^{\mathrm{NTN}}$ dominates in the PVY population in Młochów (central Poland). Similarly, in some other European countries, a progressive increase of tobacco-necrosis inducing $\mathrm{PVY}^{\mathrm{N}}$ strain in natural populations infecting potato was also noted during the last two decades (e.g. Dědič et al. 2008; Van der Vlugt et al. 2008; Lindner 2008; Rolot and Steyer 2008). In contrast, although $\mathrm{PVY}^{\mathrm{N}}$ was the dominant form $(91 \%)$ in Tunisia in 2006, it was composed from PVY ${ }^{\mathrm{NTN}}$ only, in the absence of PVY ${ }^{\mathrm{N}-W \mathrm{i}}$ (Boukhris-Bouhachem et al. 2010). In China, a 1:1 ratio of $\mathrm{PVY}^{\mathrm{O}}$ and $\mathrm{PVY}^{\mathrm{N}}$ was detected in 2008 (Bai et al. 2010). In the United States and Canada, PVY isolates were the most common, accounted for more than $60 \%$ of the population (Gray et al. 2010).

The worldwide spread of PVY ${ }^{\mathrm{NTN}}$ and $\mathrm{PVY}^{\mathrm{N}-\mathrm{Wi}}$ has been explained by their selective advantage over the parent strains (Kerlan 2003/4). In Poland, transmissibility by Myzus persicae of $\mathrm{PVY}^{\mathrm{NTN}}$ and $\mathrm{PVY}^{\mathrm{N}-\mathrm{Wi}}$ isolates has been found to be higher than that of $\mathrm{PVY}^{\mathrm{O}}$ and $\mathrm{PVY}^{\mathrm{N}}$ isolates (Kaliciak and Syller 2009) and PVY ${ }^{\mathrm{NTN}}$ was more effectively transmitted than $\mathrm{PVY}^{\mathrm{N}-\mathrm{Wi}}$ (Kostiw and Trojanowska 2011). Moreover, $\mathrm{PVY}^{\mathrm{NTN}}$ and $\mathrm{PVY}^{\mathrm{N}-\mathrm{Wi}}$ can frequently escape detection by visual inspection in seed potato certification schemes because
Fig. 1 Changes of PVY population at Młochów observed on tobacco bait plants (cv. Samsun) in potato fields from 1980 to 2010

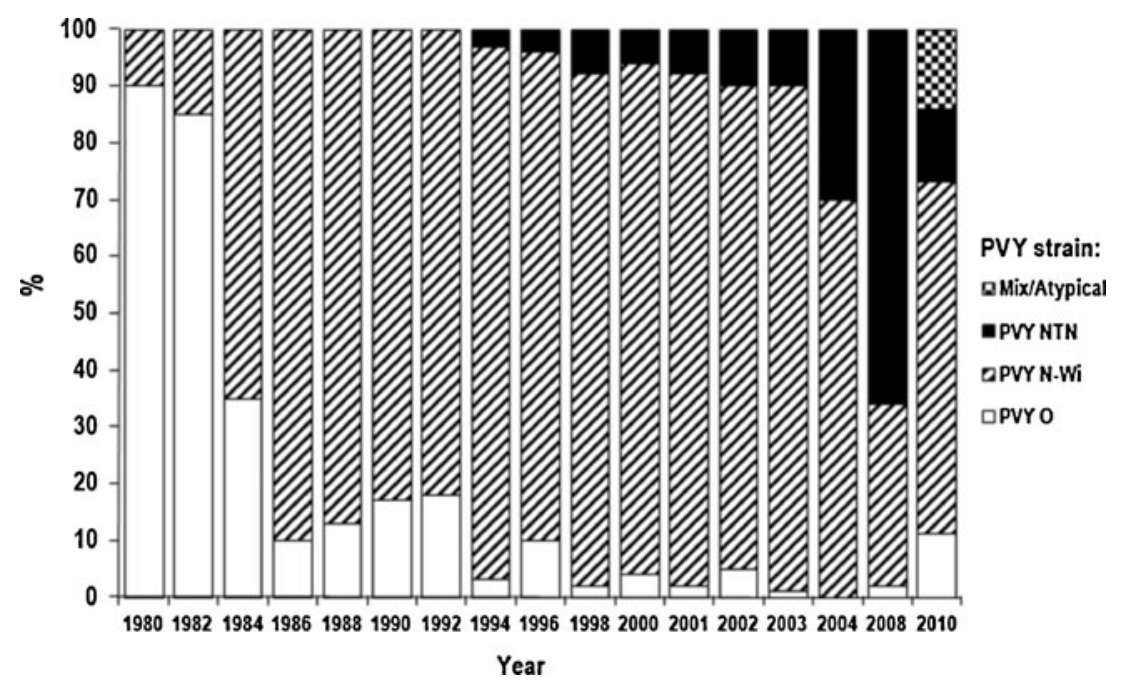


of mild symptoms on potato plants (Kerlan 2003/4). This is especially true for Polish isolates of $\mathrm{PVY}^{\mathrm{N}-\mathrm{Wi}}$ which seem to be more infective to most potato cultivars and causes mild mosaic symptoms, making negative selection in growing seed crops difficult (Chrzanowska 1994).

\section{Breeding for PVY Resistance}

The field resistance to PVY expressed under natural conditions is of polygenic nature and is present in majority of grown cultivars. Resistance related to localized infection, expressed as hypersensitive resistance (HR) or extreme resistance (ER) is governed by the major dominant genes (Solomon-Blackburn and Barker 2001). Our breeding for PVY resistance was initiated in early 1950s within a program for development of the parental lines with multiple resistances to viruses, late blight and soft rot (Świeżyński 1991). At first, resistance to PVY infection was introduced into our program from S. tuberosum. In the course of time, the resistance to infection was replaced by extreme resistance governed by the single, dominant genes (Dziewońska 1967). Various independent S. stoloniferum sources of extreme resistance were utilized in the parental line breeding program, namely: the clone XIIB from IHAR collection (Dziewońska and Pochitonow 1971), two clones C.854 and C.858 from UK (supplied by Cockerham), clones MPI 55.957/24 and MPI 55.957/54 from the Max-Planck Institute for Plant Breeding Research, Germany (Ross 1958). All these clones were male sterile, however in 1982, the exploitation of male fertile source of ER began. Such a source was identified in the accessions of $S$. stoloniferum from collection of Vavilov Research Institute of Plant Industry (VIR), Russia, which were kindly supplied by Bukasov (Butkiewicz 1988).

The resistance to PVY infection was also introduced into diploid pre-breeding program, conducted parallel to $4 x$ parental lines program. The donor of this resistance was $S$. chacoense clone PK133 from the Wyszoborz collection, Poland.

The gene $R y-f_{\text {sto }}$ from VIR source of resistance provides complete resistance to all known strains of PVY and Potato virus $A$ (PVA). The gene was mapped to chromosome XII (Flis et al. 2005) and was found to be located at the same position as $R y_{\text {sto }}$ mapped by Song et al. (2005). The developed CAPS marker GP122 718 tightly linked to resistance gene was successfully used for identification of cultivars expressing ER to PVY. The PCR product of expected size ( $718 \mathrm{bp}$ ) was found after EcoRV digestion during testing 19 Polish and 8 German (Flis et al. 2005) and, additionally, in next 5 Polish extremely resistant cultivars (Witek et al. 2006). The PCR product was not found in susceptible cultivars.

Nowadays, the GP122 marker is used for Marker Assisted Selection (MAS) in parental line breeding program. The marker is also recommended for selecting PVY resistant cultivars in commercial breeding.
Recently, the investigation of reaction to PVY in Polish cv. Rywal led to the identification of novel gene $N y-1$ mapped to the chromosome IX. Since the gene confers HR to all PVY variants, it may be considered an alternative to $R y$ genes. As expected for HR, the expression of $N y-1$ is temperature dependent: at $20^{\circ} \mathrm{C}$ common and necrotic strains of PVY were localized in inoculated plants, while at $28{ }^{\circ} \mathrm{C}$ symptomless spread of the virus was observed (Szajko et al. 2008). Further testing of cultivars expressing $H R$ to $P V Y^{N}$ infection, but lacking $R y$ gene, resulted in mapping of the $N y-1$ gene in two other cultivars Albatros and Sekwana to the same region of chromosome IX as $N y-1$ in cv Rywal. Another novel $N y-2$ gene has mapped to chromosome XI in $\mathrm{cv}$. Romula, and this gene governs temperature independent HR to $\mathrm{PVY}^{\mathrm{N}}$ infection (Szajko et al. 2012). The group of cultivars with $N y$ genes is an additional source of PVY resistance that can be used by breeders.

Development of parental lines in Młochów was initiated with an idea to increase breeding efficiency of new cultivars. These cultivars should have improved quality traits along with resistance to main potato pathogens and pests, better storability and adaptation to water deficient soils (Swieżyński 1987). Parental lines, bred in a 5 yearcycle, are donors of traits of interest, having the genetic background enriched with genes originating from various Solanum species. The fact that the parental lines combine resistances to main potato viruses with an acceptable level of agronomic traits is an important element of the breeding program. This should enhance the chance of selecting new cultivars, which are resistant to viruses. Complexity of virus resistance in parental lines has been increasing in the last four decades (Table 1).

In the 5-yearcycles of pre-breeding, breeding lines are selected for resistance to PVY, PVA, Potato virus X (PVX), Potato leafroll virus (PLRV), Potato virus $M$ (PVM) and

Table 1 Complexity of virus resistance in tetraploid parental lines offered to Polish breeders (Zimnoch-Guzowska 2012)

\begin{tabular}{lll}
\hline $\begin{array}{l}\text { Year of } \\
\text { introduction }\end{array}$ & Resistance to viruses & Gene combination* \\
\hline 1968 & PVY, PVA, PVX & $R y_{\text {sto }}, R x_{a c l}$ \\
1977 & PVY, PVA, PVX, PVS & $R y_{\text {sto }}, R x_{a c l}, N s_{a d g}$, \\
1980 & PVY, PVA, PVX, PVS, & $R y_{\text {sto }}, R x_{a c l}, N s_{a d g},(L)$ \\
& PLRV & \\
1985 & PVY, PVA, PVX, PVM, & $R y_{\text {sto }}, R x_{a c l}, R m,(L)$ \\
& PLRV & \\
1989 & PVY, PVA, PVX, PVM, & $R y-f_{\text {sto }}, R x_{a c l}, R m$, \\
& PVS, PLRV & $N s_{a d g},(L)$ \\
1993 & PVY, PVA, PVX, PVM, & $R y-f_{s t o}, R x_{a c l}, G m$, \\
& PVS, PLRV & $N s_{a d g}, P L R V 4$
\end{tabular}

*Genes for resistance to viruses: $R y_{\text {sto }}, R y-f_{\text {sto }}$ - PVY, $R x_{a c l}$-PVX, $N s_{a d g}$ PVS, Rm - PVM, Gm-PVM, PLRV4 - PLRV (from the clone DW 841457), (L) - means field resistance to PLRV from $S$. tuberosum of possible polygenic background 
Potato virus $S$ (PVS). Selection of resistant forms based on mechanical and graft inoculation and application of ELISA tests both in inoculated plants and in their tuber progeny. Additionally, stocks are exposed to a natural high virus infection pressure in Młochów experimental field and assessed by tuber indexing.

In recent years, PCR markers linked to respective resistance genes allowed combining phenotypic and genotypic selection. The MAS is introduced at the stage of the 5-year selection cycle, which is chosen on the basis of breeding priorities and number of assessed genotypes at the respective year. Nowadays markers are applied for selection of resistant forms to PVY (Flis et al. 2005; Witek et al. 2006), PVS (Marczewski et al. 2002; Witek et al. 2006) and PVM (Marczewski et al. 2006) along with resistance to Globodera rostochiensis (Milczarek et al. 2011) and sometimes to late blight (Śliwka et al. 2006). The application of mixed phenotypic selection and MAS results in an estimated $50 \%$ reduction of total costs of selection for resistance traits. In commercial cultivar breeding, where a limited number of resistance traits are tested, the use of MAS offers probably a lower reduction of the total cost of the whole breeding cycle. However, the number of lines tested for obligatory resistance traits could be reduced by the application of MAS.

Since 1967 some parental lines have been provided to Polish breeders every year. Each parental line was characterized for ca 50 agronomic, resistance and quality characters. In total 277 parental lines were offered to breeders since the beginning of the program. From direct crosses with parental lines 63 cultivars were selected and registered in Poland. The analysis of the input of the parental lines breeding program on breeding progress in Polish cultivars indicated significant influence of parental lines on starch yield in the group of starch cultivars and resistance to PVY and late blight (Fig. 2). Well represented group of

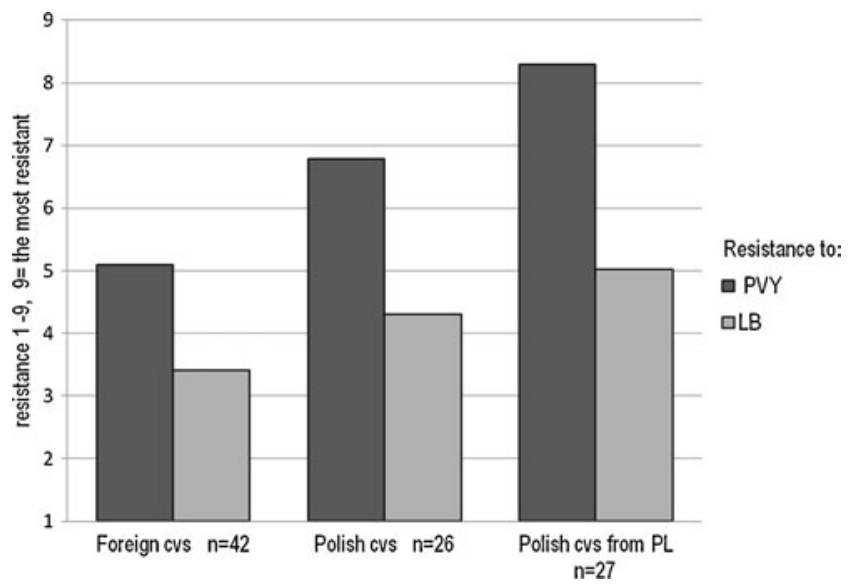

Fig. 2 Resistance to PVY and late blight (LB) in 95 potato cultivars registered in Poland since 2002 according to their origin: foreign, Polish and Polish derived form parental lines (PL) cultivars expressing ER and HR to PVY registered in 2009 in Poland mainly originated from the parental lines breeding program.

\section{Evaluation of Potato Cultivars Registered in Poland for Resistance and Reaction to PVY Strains}

Out of 133 potato cultivars registered in Poland in 2009, 113 cultivars were evaluated for resistance and reaction to four PVY isolates from the IHAR-PIB/Młochów virus collection (Table 2). In this work were used: the isolate LW (collected in 1970, accession number AJ890349), Ny (collected in 1974, FJ666337), Wi (collected in 1984, EF558545) and 12/94 (collected in 1994, AJ889866). The isolate LW induces $\mathrm{VCl}$ on tobacco and is a $\mathrm{PVY}{ }^{\mathrm{O}}$ serotype. Based on whole genome sequence it belongs to phylogenetic group $\mathrm{PVY}^{\mathrm{N}-\mathrm{Wi}}$ (Hu et al. 2009; Karasev et al. 2011). The isolate Ny induces $\mathrm{VN}$ on tobacco and is a $\mathrm{PVY}^{\mathrm{N}}$ serotype. Based on whole genome sequence it belongs to phylogenetic group recombinant PVY ${ }^{\mathrm{NTN}}$ as suggested by Hu et al. (2009). The isolate Wi induces $\mathrm{VN}$ on tobacco and is a $\mathrm{PVY}^{\mathrm{O}}$ serotype. Based on whole genome sequence it belongs to phylogenetic group $\mathrm{PVY}^{\mathrm{O}}$ (Hu et al. 2009; Ogawa et al. 2012). The isolate 12/ 94 induces $\mathrm{VN}$ on tobacco and is a $\mathrm{PVY}^{\mathrm{N}}$ serotype. It belongs to phylogenetic group recombinant $\mathrm{PVY}^{\mathrm{NTN}}$ based on whole genome sequence (Hu et al. 2009). The isolate 12/94 causes PTNRD in the majority of tested sensitive cultivars, while isolate Ny induces PTNRD only in few cultivars.

According to percentage of infected plants, infection symptoms and ELISA readings, the examined potato cultivars were classified as: (1) ER, if ELISA readings were as low as for the standard cv. Kuras and the gene $R y-f_{\text {sto }}$ was identified by MAS; (2) HR, if small necrotic lesions were observed, but the virus was not detected (ELISA values as low as for non-inoculated control); (3) relatively resistant (R), if less than $50 \%$ of inoculated plants were systemically infected and ELISA readings were higher than in healthy control; observed symptoms were different and cultivar dependent; (4) moderately resistant (mR), if 50-80\% of plants were systemically infected and ELISA values were higher than those observed in infected plants of the group $\mathrm{R}$ with varied symptoms of infection depending on cultivar; (5) susceptible (S), if all plants were infected, ELISA readings as high as in plants of susceptible cv. Zebra with symptoms dependent on cultivar. Tested cultivars were previously assessed for field resistance by the Research Centre for Cultivar Testing (COBORU) in a 1 to 9 grade scale, where 1 means susceptible and 9 extreme resistant.

As shown in Table 2, out of 113 cvs tested, 36 were resistant to all four PVY isolates. Among them there were 23 ER cultivars (with $R y-f_{\text {sto }}$ gene present in 20 ones) and $7 \mathrm{HR}$ cultivars, which were scored at 9 and 8 in the field exposure 
Table 2 Field resistance and reaction to four PVY isolates of potato cultivars registered in Poland in 2009

\begin{tabular}{|c|c|c|c|c|c|}
\hline \multirow{2}{*}{$\begin{array}{l}\text { Resistance } \\
\text { score* }\end{array}$} & \multirow[t]{2}{*}{ Cultivar } & \multicolumn{4}{|c|}{ PVY isolates } \\
\hline & & $\begin{array}{l}\text { LW } \\
(1970)\end{array}$ & $\begin{array}{l}\mathrm{Ny} \\
(1974)\end{array}$ & $\begin{array}{l}\text { Wi } \\
(1984)\end{array}$ & $\begin{array}{l}12 / 94 \\
(1994)\end{array}$ \\
\hline 9 & $\begin{array}{l}\text { Ametyst, Bzura, Eugenia, Finezja, Flaming, Hinga, Jasia, Kuba, Kuras, Owacja, Pasat, } \\
\text { Roko, Rudawa, Rumpel, Sante, Skawa, Sonda, Soplica, Selęza, Umiak, Ursus, Wiarus, } \\
\text { Zuzanna }\end{array}$ & $\mathrm{ER} * * *$ & ER & ER & ER \\
\hline 8 & Albatros, Korona, Neptun, Niagara, Romula, Sekwana, Syrena & HR & HR & HR & HR \\
\hline 8 & Bartek, Benek, Pasja Pomorska, Gandawa & $\mathrm{R}$ & $\mathrm{R}$ & $\mathrm{R}$ & $\mathrm{R}$ \\
\hline 7.5 & Ikar, Vitara & $\mathrm{R}$ & $\mathrm{R}$ & $\mathrm{R}$ & $\mathrm{R}$ \\
\hline 7.5 & Ibis, $\boldsymbol{O r l i k}^{* *}$ & $\mathrm{R}$ & $\mathrm{R}$ & $\mathrm{mR}$ & $\mathrm{mR}$ \\
\hline 7.5 & Bard & $\mathrm{R}$ & $\mathrm{mR}$ & $\mathrm{mR}$ & $\mathrm{mR}$ \\
\hline 7 & Miłek & $\mathrm{R}$ & $\mathrm{R}$ & $\mathrm{mR}$ & $\mathrm{mR}$ \\
\hline 7 & Inwestor, Medea, Pokusa, Roxana, Gracja & $\mathrm{R}$ & $\mathrm{mR}$ & $\mathrm{mR}$ & $\mathrm{mR}$ \\
\hline 7 & Irga & $\mathrm{R}$ & $\mathrm{R}$ & $\mathrm{S}$ & $\mathrm{mR}$ \\
\hline 7 & Bila & $\mathrm{R}$ & $\mathrm{mR}$ & $\mathrm{S}$ & $\mathrm{mR}$ \\
\hline 7 & Harpun, Wiking & $\mathrm{mR}$ & $\mathrm{mR}$ & $\mathrm{S}$ & $\mathrm{mR}$ \\
\hline 6.5 & Andromeda, Drop & $\mathrm{R}$ & $\mathrm{mR}$ & $\mathrm{S}$ & $\mathrm{mR}$ \\
\hline 6.5 & Żagiel & $\mathrm{mR}$ & $\mathrm{mR}$ & $\mathrm{S}$ & $\mathrm{mR}$ \\
\hline 5.5 & Agnes & $\mathrm{R}$ & $\mathrm{R}$ & $\mathrm{mR}$ & $\mathrm{S}$ \\
\hline 5.5 & Bellarosa & $\mathrm{R}$ & $\mathrm{mR}$ & $\mathrm{mR}$ & $\mathrm{S}$ \\
\hline 7.5 & Glada & $\mathrm{R}$ & $\mathrm{R}$ & $\mathrm{S}$ & $\mathrm{S}$ \\
\hline 7 & Monsun, Tara & $\mathrm{R}$ & $\mathrm{R}$ & $\mathrm{S}$ & $\mathrm{S}$ \\
\hline 7 & Tajfun, Denar, Lord, Zeus & $\mathrm{R}$ & $\mathrm{mR}$ & $\mathrm{S}$ & $\mathrm{S}$ \\
\hline 7 & Molli, Vineta & $\mathrm{mR}$ & $\mathrm{mR}$ & $\mathrm{S}$ & $\mathrm{S}$ \\
\hline 6.5 & Cedron & $\mathrm{R}$ & $\mathrm{R}$ & $\mathrm{S}$ & $\mathrm{S}$ \\
\hline 6.5 & Karlena & $\mathrm{R}$ & $\mathrm{mR}$ & $\mathrm{S}$ & $\mathrm{S}$ \\
\hline 6 & Karatop, Kolia, Ruta & $\mathrm{mR}$ & $\mathrm{mR}$ & $\mathrm{S}$ & $\mathrm{S}$ \\
\hline 5.5 & Marlen, Oman & $\mathrm{R}$ & $\mathrm{R}$ & $\mathrm{S}$ & $\mathrm{S}$ \\
\hline 5.5 & Cyprian, Elanda, Irys, Justa, Meridian, Tucan & $\mathrm{mR}$ & $\mathrm{mR}$ & $\mathrm{S}$ & $\mathrm{S}$ \\
\hline 5 & Fianna & $\mathrm{R}$ & $\mathrm{R}$ & $\mathrm{S}$ & $\mathrm{S}$ \\
\hline 5 & Asterix, Jelly & $\mathrm{mR}$ & $\mathrm{mR}$ & $\mathrm{S}$ & $\mathrm{S}$ \\
\hline 4.5 & Folva & $\mathrm{mR}$ & $\mathrm{mR}$ & $\mathrm{S}$ & $\mathrm{S}$ \\
\hline 5.5 & Ditta, Rosalind & $\mathrm{mR}$ & $\mathrm{S}$ & $\mathrm{S}$ & $\mathrm{S}$ \\
\hline 5 & Augusta & $\mathrm{R}$ & $\mathrm{S}$ & $\mathrm{S}$ & $\mathrm{S}$ \\
\hline 5 & Panda, Bryza, Satina, Zebra & $\mathrm{mR}$ & $\mathrm{S}$ & $\mathrm{S}$ & $\mathrm{S}$ \\
\hline 4 & Innovator & $\mathrm{mR}$ & $\mathrm{S}$ & $\mathrm{S}$ & $\mathrm{S}$ \\
\hline 3.5 & Ewelina & $\mathrm{mR}$ & $\mathrm{S}$ & $\mathrm{S}$ & $\mathrm{S}$ \\
\hline 5.5 & Gloria, Nora & $\mathrm{S}$ & $\mathrm{S}$ & $\mathrm{S}$ & $\mathrm{S}$ \\
\hline 5 & Fresco, Latona, Pirol, Cekin & $\mathrm{S}$ & $\mathrm{S}$ & $\mathrm{S}$ & $\mathrm{S}$ \\
\hline 4.5 & Bondeville, Lady Florina, Raja, Clarissa & $\mathrm{S}$ & $\mathrm{S}$ & $\mathrm{S}$ & $\mathrm{S}$ \\
\hline 4 & Impala, Krasa, Lady Claire, Ramos, Velox, Victoria, Amora, Redstar & $\mathrm{S}$ & $\mathrm{S}$ & $\mathrm{S}$ & $\mathrm{S}$ \\
\hline 3.5 & Berber, Courage, Courlan, Veronie, Adam, Arielle & $\mathrm{S}$ & $\mathrm{S}$ & $\mathrm{S}$ & $\mathrm{S}$ \\
\hline
\end{tabular}

*Resistance score according to Research Centre for Cultivar Testing (COBORU) in 1-9 grade scale, where $1=$ susceptible and $9=$ extreme resistant (carrying $R y-f_{\text {sto }}$ gene)

**Cultivars reacted with potato tuber necrotic ringspot disease (PTNRD by inoculation with isolate 12/94 were written in italic and bold ***ER extremely resistant (carrying $R y-f_{\text {sto }}$ gene, excluding cvs. Sante, Rudawa, Rumpel); HR hypersensitive resistant; $R$ relatively resistant; $m R$ moderately resistant; $S$ susceptible

tests, respectively. Beside, the resistance to all four isolates was observed in 6 cultivars from group $\mathrm{R}$ scored in the field at 7.5 and 8 . An additional 9 cultivars scored for the field resistance as 7 and 7.5 were classified as $\mathrm{R}$ or $\mathrm{mR}$ depending on PVY isolate. 
The 44 cultivars, with field assessments from 3.5 to 7.0 , were classified as $\mathrm{R}$ or $\mathrm{mR}$ after inoculation with the isolate $\mathrm{LW}$, but their reactions to the other three isolates were diversified. The remaining 24 tested cultivars scored for field resistance from 3.5 to 5.5 showed susceptibility to all the four isolates. Among 113 cultivars tested, 26 cultivars reacted with tuber necrotic symptoms indicative of PTNRD by inoculation with 12/94.

Most of the tested cultivars were resistant to the isolate LW. In turn, isolates 12/94 and Wi were the most infective to tested cultivars, with the exception of ER and HR cultivars. This was an additional confirmation of effective protection by the $R y-f_{\text {sto }}$ gene against old and new PVY isolates. The application of $\mathrm{Ny}$ isolate for inoculation of cultivars with field assessments below 7.5 led to changes in their classification based on reaction to the isolate LW. Namely, 23 cultivars from $\mathrm{R}$ and $\mathrm{mR}$ were downgraded to $\mathrm{mR}$ and $\mathrm{S}$ classes, respectively. In the case of cv. Augusta, the drop from $\mathrm{R}$ to $\mathrm{S}$ class was observed. The use of two new isolates Wi and 12/94 in the assessment evidenced significant breaking down of PVY resistance expressed to old isolates LW and $\mathrm{Ny}$.

Similarly to our results, Valkonen et al. (1994) reported that potato cv. Allegany reacted with hypersensitivity to an ordinary strain isolate of $\mathrm{PVY}^{\mathrm{O}}$, but was susceptible to an isolate of PVY causing necrosis in tobacco $\left(\mathrm{PVY}^{\mathrm{N}}\right)$. In Slovenia the occurrence of PVY ${ }^{\mathrm{NTN}}$ variant in the beginning of 1990s created significant losses in seed production. In 1990 and 1992 , up to 80 to $100 \%$ of seed potato fields of sensitive to $\mathrm{PVY}^{\mathrm{NTN}}$ cultivars like Igor and Vesna, Jearla, Resy or Desiree were rejected due to PVY infection (Kus 1995). In Austria Schiessendoppler (1996) noticed an increased susceptibility to PVY strain of older cultivars due to higher virulence of the $\mathrm{PVY}^{\mathrm{NTN}}$ along with stable resistance to $\mathrm{PVY}^{\mathrm{NTN}}$ of some resistant cultivars. Also McDonald and Singh (1996) indicated that several North American cultivars sensitive to PVY ${ }^{\mathrm{NTN}}$ strain expressed high or relative resistance to $\mathrm{PVY}^{\mathrm{O}}$ strain.

Acknowledgements This work was partly supported by the Ministry of Agriculture and Rural Development of the projects: "Monitoring and the assessment of changes in populations of economically important pathogens of viral, bacterial and fungal origin and pests in potato fields" (3-6-00-0-01) and "Development of new methods for potato breeding: using molecular markers in selection and obtaining duplex forms for resistance genes" (4-3-00-7-02).

Open Access This article is distributed under the terms of the Creative Commons Attribution License which permits any use, distribution, and reproduction in any medium, provided the original author(s) and the source are credited.

\section{References}

Bai, Y., X. Nie, X. Li, Y. Gao, G. Fan, W. Zhang, H. Geng, and W. Liu. 2010. The seed potato inspection and virus research in China. American Journal of Potato Research 87: 112.
Boukhris-Bouhachem, S., J. Rouze-Jouan, N. Khamassi, F. DjilaniKhouadja, H. Fakhfakh, L. Glais, M. Tribodet, and C. Kerlan. 2010. Incidence and characterization of Potato virus $Y$ in seed potatoes in Tunisia. Potato Research 53: 151-166.

Butkiewicz, H. 1988. Advances in the development of tetraploid potatoes resistant to viruses in the years 1980-1984. Proc. of the conference Genetic principles of potato breeding, February 2627, 1988, Bonin, Poland (abstract in English): 70-80.

Chrzanowska, M. 1991. New isolates of the necrotic strain of Potato virus $Y\left(\mathrm{PVY}^{\mathrm{N}}\right)$ found recently in Poland. Potato Research 34: 179-182.

Chrzanowska, M. 1994. Differentiation of potato virus Y (PVY) isolates. Phytopathologia Polonica 8: 15-20.

Chrzanowska, M., and T. Doroszewska. 1997. Comparison between PVY isolates obtained from potato and tobacco plants grown in Poland. Phytopathologia Polonica 13: 63-71.

Dědič, P., J. Ptáček, and N. Čeřovská. 2008. A shift of PVY spectrum in potatoes in the Czech Republic in past years. Potato Research 51: 198.

Dziewońska, M. 1967. Synteza form ziemniaka odpornych na wirusy. Zeszyty Problemowe Postepów Nauk Rolniczych 70: 77-88.

Dziewońska, M.A., and Z. Pochitonow. 1971. Synteza ziemniaków odpornych na wirusy. Zeszyty Problemowe Postęów Nauk Rolniczych 118: 98-118.

Flis, B., J. Hennig, D. Strzelczyk-Żyta, C. Gebhardt, and W. Marczewski. 2005. The $R y-f_{\text {sto }}$ gene from Solanum stoloniferum for extreme resistant to Potato virus $Y$ maps to potato chromosome XII and is diagnosed by PCR marker GP122 718 in PVY resistant potato cultivars. Molecular Breeding 15: 95-101.

Gray, S., S. De Boer, J. Lorenzen, A. Karasev, J. Whitworth, P. Nolte, R. Singh, A. Boucher, and H. Xu. 2010. Potato virus Y: An Evolving Concern for Potato Crops in the United States and Canada. Plant Disease 94: 1384-1397.

$\mathrm{Hu}$, X., C. He, Y. Xiao, X. Xiong, and X. Nie. 2009. Molecular characterization and detection of recombinant isolates of potato virus Y from China. Archives of Virology 154: 1303-1312.

Jeffries, C.J. 1998. Potato. FAO/IPGRI Technical Guidelines for the Safe Movement of Germplasm. No 19.

Kaliciak, A., and J. Syller. 2009. Aphid transmissibility of genetically different isolates of Potato virus Yand susceptibility of weeds to virus infection. (in Polish). Biuletyn Instytutu Hodowli i Aklimatyzacji Roślin 253: 285-295.

Karasev, A.V., X. Hu, C.J. Brown, C. Kerlan, O.V. Nikolaeva, J.M. Crosslin, and S.M. Gray. 2011. Genetic diversity of the ordinary strain of Potato virus $Y$ (PVY) and origin of recombinant PVY strains. Phytopathology 101: 778-785.

Kerlan, C. 2003/4. Evolution in Potato virus Y: from recombination in the genome to emergence and spreading of variants. Potato Research 46: 184.

Kostiw, M., and E. Trojanowska. 2011. Impact of feeding time on $\mathrm{PVY}^{\mathrm{N}}$ and PVY ${ }^{\mathrm{NTN}}$ transmission by Myzus persicae (Sulz.). Journal of Plant Protection Research 51: 429-434.

Kus, M. 1995. The epidemic of the tuber necrotic ringspot strain of potato virus $\mathrm{Y}\left(\mathrm{PVY}^{\mathrm{NTN}}\right)$ and its effect on potato crops in Slovenia. Proc. of the $9^{\text {th }}$ EAPR Virology Section Meeting, June 18-22, 1995, Bled, Slovenia: 159-160.

Lindner, K. 2008. PVY strains in Germany-the period between 1984 2006. Potato Research 51: 202.

Marczewski, W., J. Hennig, and C. Gebhardt. 2002. The Potato virus S resistance gene Ns maps to potato chromosome VIII. Theoretical and Applied Genetics 105: 564-567.

Marczewski, W., D. Strzelczyk-Zyta, J. Hennig, K. Witek, and C. Gebhardt. 2006. Potato chromosomes IX and XI carry genes for resistance to potato virus M. Theoretical and Applied Genetics 112: $1232-1238$.

McDonald, J.G., and R.P. Singh. 1996. Response of potato cultivars to North American isolates of PVY ${ }^{\mathrm{NTN}}$. American Potato Journal 73: $317-323$. 
Milczarek, D., B. Flis, and A. Przetakiewicz. 2011. Suitability of Molecular Markers for Selection of Potatoes Resistant to Globodera spp. American Journal of Potato Research: 88: 245-255.

Novy, R.G., A. Nasruddin, D.W. Ragsdale, and E.B. Radcliffe. 2002. Genetic resistances to potato leafroll virus, potato virus $\mathrm{Y}$ and green peach aphid in progeny of Solanum etuberosum. American Journal of Potato Research 79: 9-18.

Ogawa, T., A. Nakagawa, T. Hataya, and K. Ohshima. 2012. The Genetic Structure of Populations of Potato virus Y in Japan; Based on the Analysis of 20 Full Genomic Sequences. Journal of Phytopathology. doi:10.1111/j.1439-0434.2012.01959.x.

Rolot, J.L., and S. Steyer. 2008. First screenings of the different PVY strain in Belgium. Potato Research 51: 204.

Ross, H. 1958. Resistenzzüchtung gegen die Mosaic- und andere Viren der Kartoffel. In Handbuch der Pflanzenzüchtung, Vol. III, 2nd ed, ed. H. Kappert and W. Rudorf, 106-125. Berlin and Hamburg: Paul Parey.

Schiessendoppler E. 1996. Change of susceptibility of potato cultivars to PVY-strain group as response of PVY-NTN introduction. 13th triennial conference of the European Association of Potato Research, July 14-19, 1996, Veldhoven, Netherlands: $310-311$.

Śliwka, J., H. Jakuczun, R. Lebecka, W. Marczewski, C. Gebhardt, and E. Zimnoch-Guzowska. 2006. The novel, major locus Rpi-phul for late blight resistance maps to potato chromosome IX and is not correlated with long vegetation period. Theoretical and Applied Genetics 113: 685-695.

Solomon-Blackburn, R.M., and H. Barker. 2001. A review of host major-gene resistance to potato viruses $\mathrm{X}, \mathrm{Y}, \mathrm{A}$ and $\mathrm{V}$ in potato: genes, genetics and mapped locations. Heredity 86: 8-16.

Song, Y.-S., L. Hepting, G. Schweizer, L. Hartl, G. Wenzel, and A. Schwarzfischer. 2005. Mapping of extreme resistance $\left(R y_{s t o}\right)$ on chromosome XII using anther -culture-derived primary dihaploid potato lines. Theoretical and Applied Genetics 111: 879-887.
Swieżyński, K.M. 1987. Potato breeding strategy in Poland. In the production of new potato varietes, ed. G.J. Jellis and D.E. Richardson, 55-59. Cambridge: Cambridge University Press.

Świeżyński, K.M. 1991. Synteza materiałów wyjściowych dla hodowli ziemniaka - podsumowanie dorobku. In Development of parental lines for potato breeding - results and prospects for the future, 1991: 9-16. Instytut Ziemniaka. Bonin.

Szajko, K., M. Chrzanowska, K. Witek, D. Strzelczyk-Żyta, H. Zagórska, C. Gebhardt, J. Hennig, and W. Marczewski. 2008. The novel gene $\mathrm{Ny}-1$ on potato chromosome IX confers hypersensitive resistance to Potato virus $Y$ and is an alternative to Ry genes in potato breeding for PVY resistance. Theoretical and Applied Genetics 116: 297-303.

Szajko K., D. Strzelczyk-Żyta, W. Marczewski. 2012. The development of diagnostic markers for selection of hypersensitive response (HR) genes for resistance to PVY in cultivated potato. Abstracts SOL2012 the 9th Solanaceae Conference: From the bench to Innovative Applications, August 26-30, 2012, Neuchatel, Swiss: 156.

Valkonen, J.P.T. 2007. Viruses: Economical Losses and Biotechnological Potential. In Potato Biology and Biotechnology: Advances and Perspectives, ed. D. Vreugdenhil, 619-641. Elsevier B.V..

Valkonen, J.P.T., S.A. Slack, and R.L. Plaisted. 1994. Use of the virus strain group concept to characterize the resistance to $\mathrm{PVX}$ and $\mathrm{PVY} \mathrm{O}^{\mathrm{O}}$ in the potato cv. Allegany. American Potato Journal 71: 507-516.

Van der Vlugt, R.A.A., M. Verbeek, C. Cuperus, P.G.M. Piron, D. De Haan, and G.W. Van de Bovenkamp. 2008. Strains of Potato virus $Y$ in Dutch seed potato culture. Potato Research 51: 191.

Witek, K., D. Strzelczyk-Żyta, J. Hennig, and W. Marczewski. 2006. A multiplex PCR approach to simultaneously genotype potato towards the resistance alleles $R y-f_{\text {sto }}$ and Ns. Molecular Breeding 18: $273-275$.

Zimnoch-Guzowska, E. 2012. Genetyczne podstawy postępu biologicznego w produkcji ziemniaka. In Produkcja i rynek ziemniaka, ed. J. Chodkowski, 46-56. Warszawa: Wieś Jutra. 